\title{
FORTY-YEAR SURVIVAL OF A JUDET HIP PROSTHESIS: A CASE REPORT
}

\author{
J. HETTFLEISCH, R. WISSENBACH
}

In 1946, the Judet brothers performed their first 'resectionreconstruction' of the femoral head (Judet 1947) using a prosthesis made entirely of polymethylmethacrylate (PMMA). The early implants broke frequently and were later reinforced by a steel rod (Judet and Judet 1950). Failures continued, however, and use of the prosthesis was abandoned decades ago.

Case report. In 1952, a 12-year-old girl had a Judet hip arthroplasty for degenerative changes secondary to congenital hip dislocation (Fig. 1). Seven years later she felt some pain and was told that the implant had migrated (Fig. 2), but she was then lost to follow-up. In 1984 she had total replacement of the opposite hip for pain greater than that in the loosened acrylic prosthesis (Fig. 3). connective tissue around the loose rod. Histological examination of the thickened capsule of the joint was reported to show degenerate and hyalinised scar tissue with mucoid and chondroid patterns, but no birefringent debris. The head of the implant was worn (Fig. 4) although intra-articular debris was neither obvious nor histologically detected. The patient had a good painless result after cementless revision.

Discussion. Other very long-term results of hip replacement are rare. Joshi et al (1993) reported the 24-year survival of a Charnley-type prosthesis and Zaoussis and Patikas (1989) reported two McKee-type implants still in situ after 20 years. PMMA proved to be an inappropriate material for endoprostheses, although Rushton, Hart and

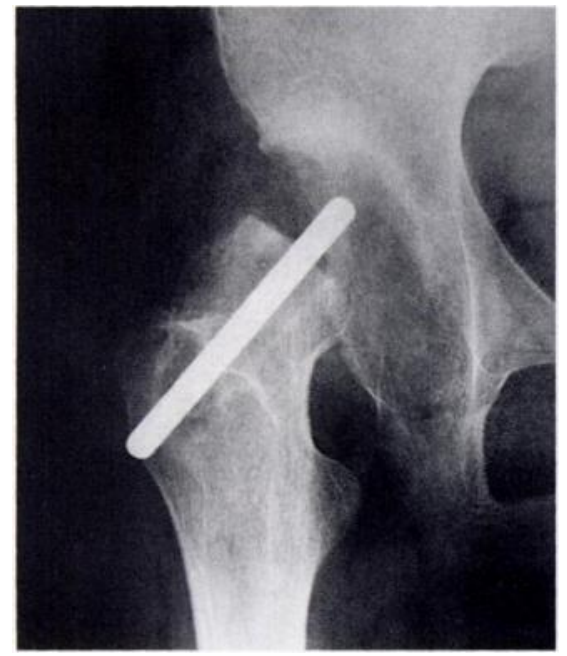

Fig. $1-1952$

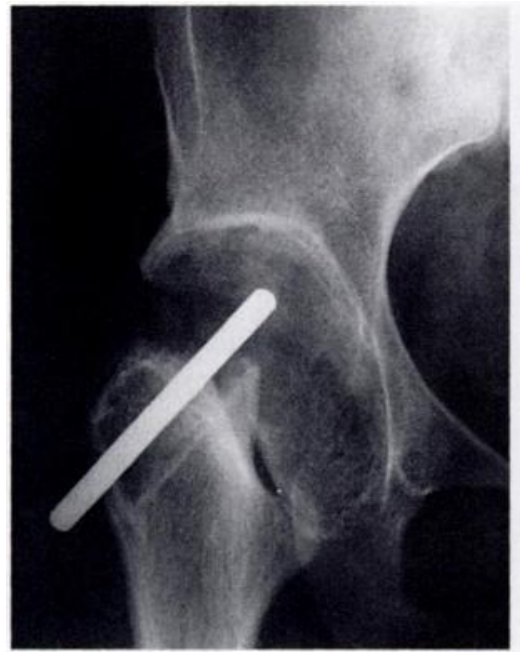

Fig. $2-1959$

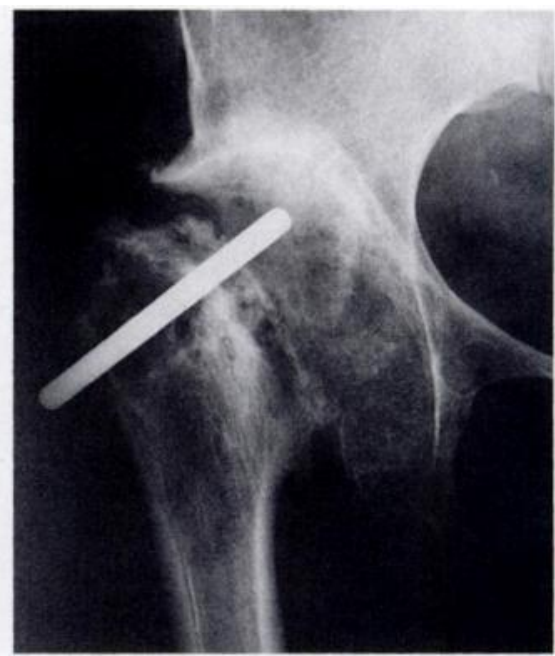

Fig. $3-1982$

By 1992, at the age of 52 years walking disability and pain had intensified although migration had not increased significantly. Hip flexion was $60^{\circ}$ with a flexion contracture of $10^{\circ}$. Rotation and abduction were very limited. At the operation it could be seen that the rod of the implant had migrated into the vastus lateralis, and the remnant of the femoral neck was necrotic with a layer of

\footnotetext{
J. Hettfleisch, MD, Senior Resident

R. Wissenbach, MD, Senior Resident

Department of Orthopaedics, Mannheim Medical School, University of Heidelberg, Meerfeldstrasse 69, 68163 Mannheim, Germany.

Correspondence to Dr J. Hettfleisch.
}

C1994 British Editorial Society of Bone and Joint Surgery 0301-620X/94/4R15 \$2.00

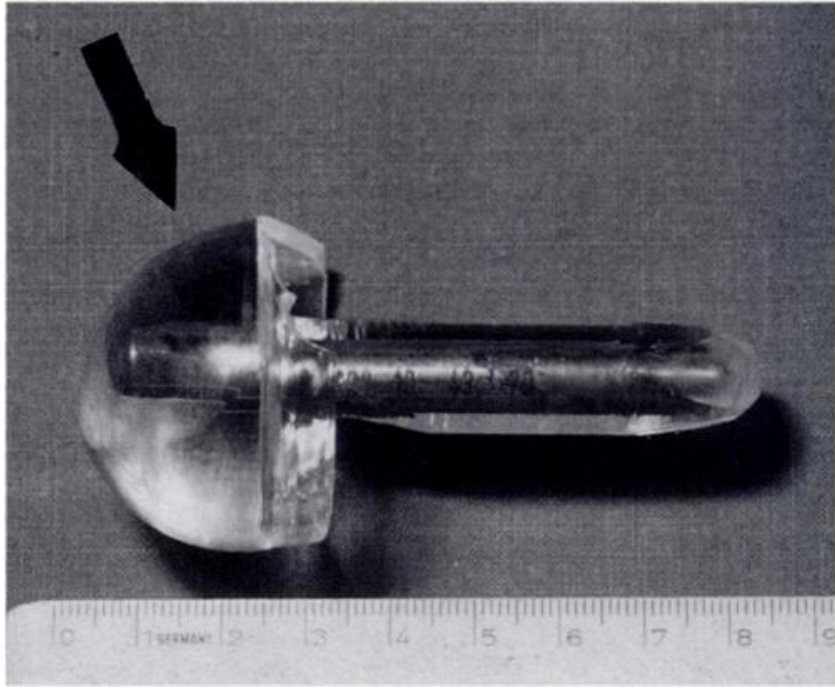

Fig. 4- 1992 
Arden (1979) found three Judet prostheses followed up for 20 to 22 years. Our case demonstrates the histocompatibility of the acrylic material especially since the implant was probably never securely fixed. We know of no other 40-year follow-up for any type of joint prosthesis.

We wish to acknowledge and thank Dr R. Bremer from the Orthopaedic Department at the University of Heidelberg for his assistance with the investigation of this case.

No benefits in any form have been received or will be received from a commercial party related directly or indirectly to the subject of this article.

\section{REFERENCES}

Joshi AB, Porter ML, Trail IA, et al. Long-term results of Charnley lowfriction arthroplasty in young patients. J Bone Joint Surg [Br] 1993; 75-B:616-23.

Judet J. Prothèses en résine acrylic. Mém Acad de Chir 1947; 73:561.

Judet $\mathbf{J}$, Judet $\mathbf{R}$. The use of an artificial femoral head for arthroplasty of the hip joint. J Bone Joint Surg [Br] 1950; 32-B:166-73.

Rushton N, Hart GM, Arden GP. The Judet prosthesis: a long term follow-up of three cases and a review of the literature. Injury 1979; 11:49-51.

Zaoussis AL, Patikas AF. Experience with total hip arthroplasty in Greece, the first 20 years: a particular reference to long-term results with the McKee-Farrar technique. Clin Orthop 1989; 246:39-47.

\title{
CENTRAL SPINAL STENOSIS DUE TO PSEUdOGOUT: A CASE REPORT
}

\author{
TANVEER SADIQUE, JOHN G. BRADLEY, ALAN M. JACKSON
}

We describe a hitherto unreported cause of central spinal stenosis in which narrowing of the lumbar canal was confirmed by CT and pseudogout was diagnosed by the identification of typical calcium pyrophosphate crystals in material obtained from the spinal canal at laminectomy. Case report. In May 1992 a 75-year-old non-smoking, healthy woman was referred by her doctor to a vascular surgeon with a history of bilateral intermittent claudication gradually becoming worse. She complained of pain in both calves, knees and ankles which was made worse by walking, especially uphill, and not completely relieved by rest. She had normal pedal, popliteal and femoral pulses, but there was varicose eczema on both legs. She had had varicose vein surgery in both legs in 1990 and deep-vein thrombosis in the left leg after the operation. A working diagnosis of venous claudication was made.

In October 1992 she was admitted under the care of a vascular surgeon for investigation as she continued to complain of increasing pain. Haematology, biochemistry, plasma viscosity, Doppler ultrasound, venography and plethysmography were all normal. Transfemoral aortography was reported to be normal but marked chondrocalcinosis was noted in the knees which could have contributed to the leg pain. The appearance was that of a pyrophosphate deposition arthritis (Fig. 1). The patient was referred to the orthopaedic department with continu-

T. Sadique, FRCS, Senior Orthopaedic Registrar

J. G. Bradley, FRCS, Consultant Orthopaedic Surgeon

A. M. Jackson, BSc, FRCPath, Consultant Histopathologist

Department of Orthopaedic Surgery, Scarborough Hospital, Woodlands Drive, Scarborough, North Yorkshire YO12 6QL, UK.

Correspondence to Mr T. Sadique at St James's University Hospital, Chancellor's Wing, Beckett Street, Leeds LS9 7TF, UK.

C1994 British Editorial Society of Bone and Joint Surgery 0301-620X/94/4R11 \$2.00

J Bone Joint Surg [Br] 1994; 76-B:672-3.

Received 8 July 1993; Accepted 14 October 1993 ing pain from the hips to the toes and tingling throughout both legs. She did not complain of backache. There was a full and painfree range of movement of the lumbar spine and no objective neurological deficit was noted.

Blood urate and uric acid levels were normal and plain radiographs of the lumbar spine showed moderate intervertebral disc degeneration, and facet joint degeneration at L4, L5 and S1 levels. Calcification, visible between the pedicles of L4, L5 and S1, was overlooked.

CT revealed extensive calcification of the ligaments of the spine (Fig. 2), particularly marked at the L4, L5 levels where there was also calcification within the spinal canal, narrowing its AP diameter at this level.

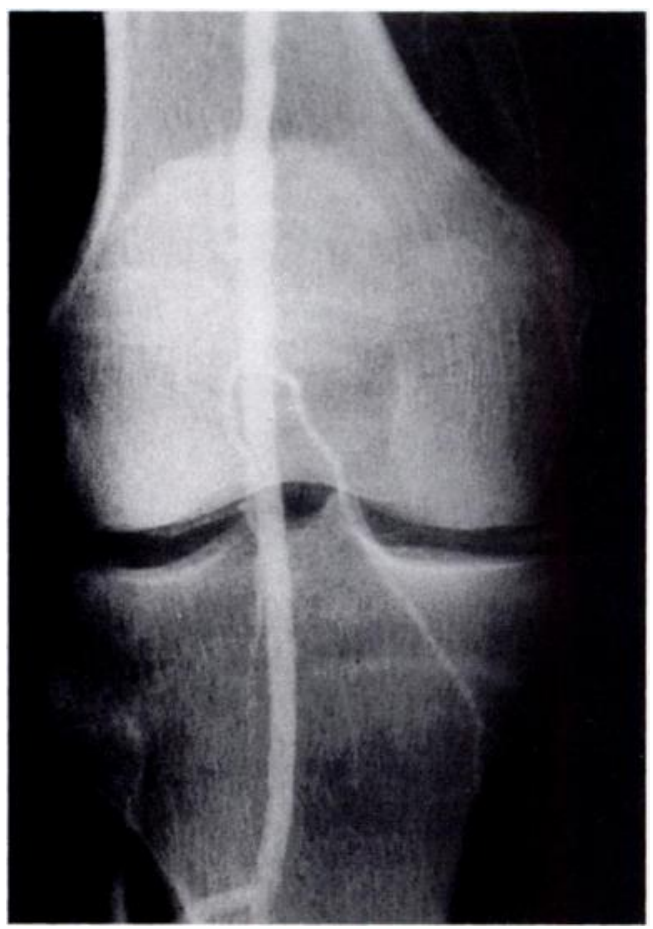

Fig. 1 